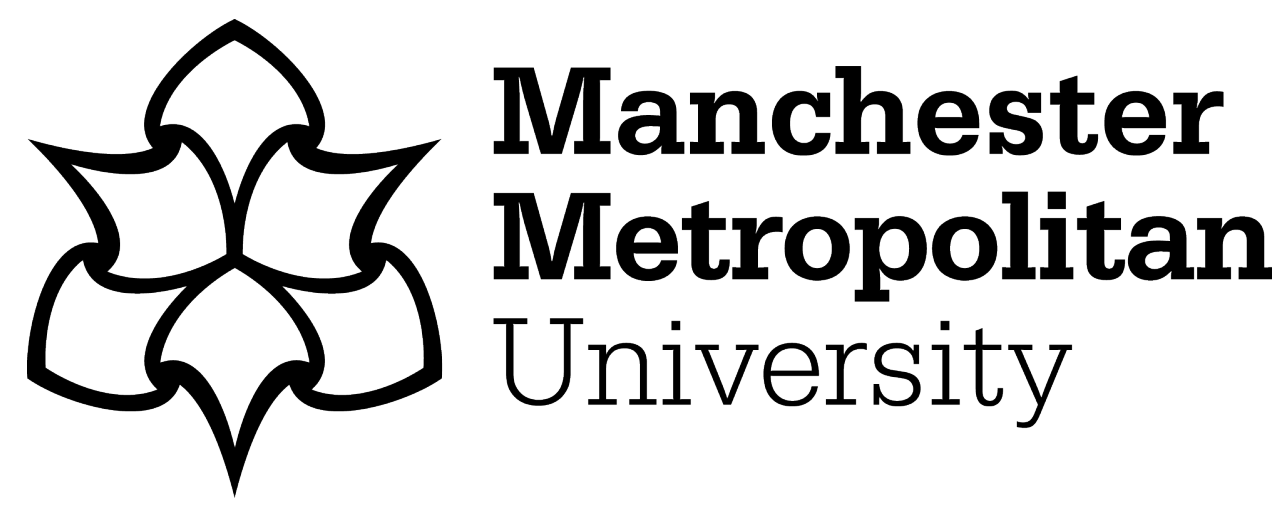

Okunola, Olaseni Muritala and Rowley, Jennifer ORCID logoORCID: https://orcid.org/0000-0003-3437-6914 (2019) User experience of egovernment: the Nigeria Immigration Service. Library Hi Tech, 37 (3). pp. 355-373. ISSN 0737-8831

Downloaded from: https://e-space.mmu.ac.uk/623413/

Version: Accepted Version

Publisher: Emerald

DOI: https://doi.org/10.1108//ht-09-2018-0138

Please cite the published version 


\title{
User Experience of e-Government: the Nigeria Immigration Service
}

\begin{abstract}
:
Purpose - This article identifies key considerations influencing the adoption and use of egovernment services by providing insights into users' views of their experience of an egovernment service in a developing country, the website of the Nigeria Immigration Service (NIS).

Design/methodology/approach - An online questionnaire-based survey was conducted to capture perceptions of the user experience with the NIS website. Descriptive statistics for each of the factors that contribute to the user experience are reported and discussed, with reference to open comments and previous literature. These factors are security and support, trust, ease of use, website quality, content and information, perceived benefits, convenience, and perceived barriers.

Findings - There is strong evidence of concern in relation to the security of financial transactions, the use of personal data, and trustworthiness, which is aggravated by inadequate user support. There is a lack of consensus regarding ease of use, website quality, and content and information. In terms of barriers and benefits, there was a general agreement that the website offered greater convenience than alternative channels, but some concerns were identified regarding the reliability of technology, and, for users in Nigeria, the reliability of the electricity supply.
\end{abstract}

Originality/value - This article adds to the very sparse literature on e-government in Nigeria, as well as extending consideration of the public value approach to e-government in developing countries.

Keywords e-government, Nigeria, citizen satisfaction, security and support, user experience, adoption, public value

\section{Research paper}




\section{Introduction}

Governments worldwide have introduced e-government services in order to reduce costs and make their operations more efficient, provide prompt service, improve service quality, remove barriers to government services, tackle social exclusion, and, provide local access points (Praeg and Spath 2010; Asogwa, 2013; Rana and Dwivedi, 2015; Abu-Shanab, 2017). Typical applications include information provision, downloading of forms, interaction, service delivery, and e-democracy (Al Ajeeli and Al-Bastaki, 2011; Siddiquee, 2016; Oni et al., 2016, Sampson et al., 2018).

For developing countries, the implementation of e-government promises a range of potential social, economic, and political benefits, and can make a signficant contribution to the development of information technology infrastructures, and raising citizen skills in the implementation and use of information and communication technologies (Dwivedi, 2009; Lee and Lei, 2007; Yonazi et al.; 2010, Amagoh, 2015). However, there is evidence that developing countries struggle to achieve successful implementation and adoption of egovernment (Reddick, 2010; Hassan et al, 2011; Al-Refaie and Ramadna, 2017). For example, Heeks (2006) and Gunawong and Gao (2017) suggest that successful implementation and development of e-government is often hampered by lack of resources and finance, Reddick (2010) suggests that the problem lies with not achieving aims and objectives, and Lee and Lei (2007) point to the lack of adequate strategies. More poignantly, Mundy and Musa (2010) and Ciborra (2005) argue that the implementation of e-government services is not well-suited to developing countries, such as Nigeria, as political, social and cultural changes to re-shape the trust that citizens are prepared to place in their government are necessary. Finally, deficiencies in basic technological infrastructure, coupled with a lack of user experience may affect the success of the implementation of e-government systems in developing countries (Dimitrova and Chen, 2006; Rokhman, 2011; Waller and Genius, 2015; Carter et al, 2016). Ultimately, the success of e-government can be judged by the extent of user adoption and user satisfaction (Al Athmay et al., 2016), together with e-government's contribution to public value (Scott et al., 2016).

This article reports on a study of the user experience of the Nigeria Immigration Service (NIS) website. This service has been chosen as the basis for this study because Nigeria is a large and important African developing country, and as Olasina (2012) suggests 'there are limited academic writings on this subject with reference to Nigeria' and, in particular 'there is no literature on empirical findings on citizens' views, satisfaction and requirements for better 
e-government services'. In addition, the NIS e-service has been lauded as a relatively successful e-government service (Yusuf, 2006; Abdulkareem, 2015).

The aim of this study is, then, to provide insights into users' perceptions of their experience of the e-government service delivered through the NIS website. More specifically, the objectives are to:

1. Offer insights into the users' perceptions of the problems associated with each of the aspects of the user experience.

2. Identify those aspects of the user experience that could be improved

3. Make recommendations for service quality improvements, and for further research.

The next section of the paper distils previous research on the evaluation of e-government services and the citizen/user experience. The methodology section explains the design of the data collection instrument, and the processes associated with the online survey and data analysis. The findings and discussion section reports, and discusses, the profile of users, and descriptive statistics in respect of aspects of the user e-government experience, together with text responses to the open question. Finally, the conclusions and recommendations section summarizes the contribution of the research and makes recommendations for further research.

\section{Literature Review}

The need to encourage citizen adoption of e-government technologies has led to an increasing interest in the evaluation of e-government services, often in terms of citizen or customer satisfaction and notions of e-government service quality and impact. Halaris et al. (2007) classify the approaches to measuring the quality of e-government into three categories concerned, respectively, with: the quality of traditional public service (e.g. balanced scorecard and six sigma); the quality of e-government services (e.g. the American Customer Satisfaction that this article will fill Index (ACSI); and the quality of e-services (e.g. E-S-QUAL, E-Qual, E-service quality). Halaris et al. (2007) suggest the following criteria as often being used in the studies that they reviewed: service reliability, personalisation, information/content, navigation/accessibility, security, and system performance. Similarly, the features that researchers have identified as contributing to e-service quality are: site features, security, communication, reliability, customer support, responsiveness, information, accessibility, delivery and personalisation (Rowley, 2006). Others have used the Technology Adoption Model (TAM) and/or the Diffusion of Innovation model (DOI) as the basis for their study. For example, Carter and Belanger (2005) used both TAM and DOI, and found that perceived 
ease of use, compatibility, and trustworthiness were important in e-government adoption. Together, these approaches to research on the user experience of, and response to egovernment have generated a wide range of different variables for consideration for inclusion in this research.

Other research has explored the benefits and barriers to the use e-government services. Gilbert et al. (2004) argue that it is important to consider both the positive and the negative factors that influence adoption. For example, there is evidence that users believe they benefit from savings in cost (Liao and Cheung, 2002; Ashaye and Irani, 2014) and time (Liao and Cheung, 2001, 2002; Meuter et al., 2000; Ashaye and Irani, 2014). On the other hand, according to Idowu et al. (2009), major barriers to successful e-government include access to technology, citizen's reluctance to trust e-government services, based on and their concerns regarding privacy, information quality and financial security (Dibbell, 2012; Gilbert et al., 2004; Parker, 2011; Amagoh, 2016).

Despite the potential importance of e-government to Nigeria, only a few studies have considered the user experience of e-government in Nigeria. Yusuf (2006) and Amagoh (2015) conducted studies of the extent of implementation in Nigeria and found it to be low. Mundy and Musa (2010) compared the functionality of Nigerian e-government websites with UK egovernment websites, and found them to be lacking in security and privacy policies, and relative to UK websites, low in usability, and in the extent of their information content. Kazeem (2011) is the only article that reports in detail on the user experience of e-government in Nigeria; their findings raise some serious concerns regarding personal privacy, possibility of fraud and crime, insecure cookies, and unauthorized access to personal information.

\section{Methodology}

\section{Context}

Nigeria's e-government system aims to enhance internal efficiency, public services and democratic processes in the legislation and administration section of the public sector (Aneke, 2009). The early implementation of e-government in Nigeria was managed by the Nigerian Port Authority, and was subsequently taken over by the Nigerian Immigration Service. (Sampson et al., 2018; Adeyemo, 2011; Adeniran, 2008). According to Okwuke (2013), the Nigerian government's aim is to promote its e-government services as a catalyst for national development. This study is based on the e-services offered by the Nigeria Immigration 
Service (NIS). The Nigerian Immigration Service (NIS) controls and monitors entry and exit activities in Nigeria. It has developed e-services to support information distribution among citizens, form processing, and financial transactions, including online payment for new passports, passport renewal, visa applications, and the processing of various other entry permits (Kanat and Ozkan, 2009).

The NIS e-services are of particular interest because they are accessed by both citizens and non-citizens, and by residents of Nigeria and Nigerian national elsewhere in the world. In addition, the web site both offers information, and supports transactions. If the user wishes to move in and out of Nigeria, they are forced to adopt the system, meaning that insights from the evaluation of this service relate to both willing and reluctant users. Importantly, whilst there is evidence that Nigeria is facing significant challenges in the implementation of egovernment (Akunyili, 2010; Omeire and Omeire, 2014), the NIS is acknowledged to be one of the few successful e-government implementations in Nigeria (Yusuf, 2006; Abdulkareem, 2015).

\section{Research approach}

This study adopted a quantitative, survey-based research design, in order to develop a profile of website users' attitudes towards the NIS e-government service. A quantitative approach is regarded as useful for profiling a situation (Oppenheim, 2000). In addition, an online questionnaire-based survey was particularly appropriate for this study, since potential respondents were scattered across the globe. In addition, given the potential diversity of the population a reasonably large sample was judged to be necessary (Creswell and Creswell, 2017).

\section{Measurement}

In order to identify the key variables to be included in the questionnaire and their associated items, a database of items used by a wide range of previous studies, including those in the technology adoption, diffusion of innovation, customer satisfaction and service quality traditions was collated. Table 1 summarizes the sources of the items (questions) used in this research and Appendix 1 lists the items. from the previous researches. These items were framed as statements with accompanying 5-point Likert scales $(1=$ strongly disagree, $2=$ disagree, 3 = neither agree nor disagree, 4 =agree, $5=$ strongly agree). Complementing these closed questions, an open question invited respondents to provide additional comments on the 
NIS website and its e-services. Finally, closed questions were developed to collect demographic data including gender, age, education, income, employment sector, abode (country of permanent residence), and localization (rural or urban dwellers). Questions were also included on previous experience with information technologies and with e-government services.

\begin{tabular}{|l|l|l|}
\hline Construct & Number of Items & Adapted from \\
\hline Barriers & 11 & Zhang and Prybutok (2005) \\
\hline Benefits & 11 & Parasuraman et al., (2005) \\
\hline Ease of use & 10 & Davis et al., (1989) \\
\hline $\begin{array}{l}\text { Content and } \\
\text { information }\end{array}$ & 10 & Aladwani and Palvia (2002) \\
\hline Trustworthiness & 11 & Parent et al., (2007) \\
\hline User satisfaction & 9 & Zhang and Prybutok (2005) \\
\hline Website quality & 10 & $\begin{array}{l}\text { Yoo and Donthu (2001); Parasuraman et al. } \\
(2005) ; \text { Zhang and Prybutok (2005) }\end{array}$ \\
\hline
\end{tabular}

\section{Table 1: Variables included in the questionnaire}

The online survey was designed in such a way that respondents could not proceed to other pages of the questionnaire without completing all of the questions on the current page; this helped to minimize any potential problems with missing data. In addition, the questionnaire screened out participants who had never used the NIS e-services. The questionnaire was piloted to remove any inconsistencies and to confirm its wording, structure and design. Piloting also offered insights into the responses to the questionnaire and its comprehensibility (Oppenheim, 2000).

\section{Data Collection and analysis}

The online survey was available for nine weeks. Respondents were directed to the survey by e-mail; an initial and two reminder e-mails were sent to each identified respondent. Respondents were identified and contacted via snowball sampling. 351 completed questionnaires were returned.

Data was loaded into SPSS 19.0 for analysis. First, data was cleaned to remove any incomplete or inaccurate responses. Appendix 1 shows the variables, and items that remained after Exploratory Factor Analysis. Descriptive statistics were then generated, both to profile the sample in terms of demographic data, and to generate descriptive statistics for the Likert 
scale items. Finally, the data from the responses to the open question were entered into nVivo version10 and analysed.

\section{Participants}

All respondents confirmed that they had used the NIS website. In terms of gender, the sample was split (Male 50.1\% v Female 49.9\%). Of the respondents not living in Nigeria, the largest groups were those living in United Kingdom (22.5\%), United States (9.1\%) and Canada (4.3\%). All respondents were in the age range of 18 to 65 years and there was a fairly even distribution between age categories. Education levels varied, but the sample was relatively well educated, with $67 \%$ having a Bachelor's degree or above, $17 \%$ having a Higher Diploma and $9 \%$ having a Diploma. In terms of employment status, the distribution was: public sector $(16.5 \%)$, private sector $(32.8 \%)$, self-employed $(23.9 \%)$, unemployed $(6.3 \%)$, retiree $(0.9 \%)$ and students (19.6\%). Respondents classified themselves in terms of income as: low-income earners (44.2\%), medium income earners (33.3\%) and high-income earners $(22.5 \%)$.

\begin{tabular}{|c|c|c|c|}
\hline \multicolumn{4}{|l|}{ Demographic Profile of Respondents } \\
\hline Location (Country) & $\%$ & Gender & $\%$ \\
\hline Nigeria & 50.4 & Male & 50.1 \\
\hline Other ( UK, US, Canada etc.) & 49.6 & Female & 49.9 \\
\hline \multicolumn{2}{|l|}{ Location (Urb } & Age & $\%$ \\
\hline Urban & 84.6 & Young (18 -30years) & 28.1 \\
\hline \multirow{2}{*}{\multicolumn{2}{|c|}{ Rural }} & Middle (31 to 50 years) & 52.4 \\
\hline & & Older (51yrs and above) & 19.5 \\
\hline \multicolumn{4}{|l|}{ Education Status } \\
\hline Well educated (PhD and Masters) & 25.7 & Employment Status & \\
\hline $\begin{array}{l}\text { Moderately Educated (Bachelors and } \\
\text { HNDs) }\end{array}$ & 57.5 & Government Employee & 16.5 \\
\hline $\begin{array}{l}\text { Fairly Educated (Diploma, Technical, } \\
\text { Secondary and Primary School) }\end{array}$ & 16.5 & Private Sector Employee & 32.8 \\
\hline \multirow{2}{*}{\multicolumn{2}{|c|}{ Not Formally educated }} & Self Employed & 23.9 \\
\hline & & Unemployed & 6.3 \\
\hline Income Level & & Retiree & 0.9 \\
\hline Low & 44.2 & Student & 19.6 \\
\hline Medium & 33.3 & & \\
\hline High & 22.5 & & \\
\hline
\end{tabular}

Table 2: Demographic profile of respondents 


\section{Findings and Discussion}

\section{Introduction}

Appendix 1 contains the descriptive statistics for responses to the Likert style questions relating to the user experience with the NIS e-government service. This data is presented after Exploratory Factor Analysis using PCA was conducted to confirm the original variables and their associated items. It is not our purpose in this article to report the details of the EFA, because the focus is on the descriptive statistics, but we have included the Cronbach alpha values for each of the factors in the table in Appendix 1 in order to show that the items loaded onto each factor are suitable measures. We have chosen to present this version rather than a pre-EFA version, because the EFA analysis surfaced two important new variables. First, a number of items on security and support loaded onto one factor, rather than being scattered across variables, as they were in the questionnaire design. Secondly, items relating to convenience, originally part of the measure for perceived benefits, clustered as a separate group. On this basis, the factors that emerged from the EFA were security and support, trust, ease of use, website quality, content and information, perceived benefits, convenience, and perceived barriers. Responses in each of these areas are reported in turn below. The insights from the descriptive statistics are further elucidated by comments drawn from the responses to the open question.

\section{Security and Support}

Respondents indicated a high level of negativity towards being required to use the NIS website, and much of their concerns stemmed from issues associated with security and support. In the first instance, $86.6 \%$ indicated that they had reason not to want to use the website. Users are concerned about their financial details being stolen, and their personal information being used by others; $90.9 \%$ either agreed or strongly agreed with the statement 'I worry about my financial details being stolen', whilst $92.3 \%$ either agreed or strongly agreed with the statement 'I worry about my personal information being used by others'. They are also generally concerned about engaging in transactions, with $92.8 \%$ either agreeing or strongly agreeing with the statement 'I worry about safe transactions online'. This quantitative analysis is supported by responses to the open question:

'the service payment system is too high risk considering you have to put in a personal document detailing your information which can make it easy for fraud activity to happen'. 
'I fear continuing with the financial transaction but have no other choice but to do it and live in fear of not knowing what is going to happen next'

'I fear data being used by others and not for the purpose it was obtained for by the immigration service'

These concerns were not allayed by respondents' view that the NIS website policy was not clearly stated and accessible. One respondent commented:

'no clear policy on data protection and security of financial transactions is stated on the Nigeria Immigration Service website'

Given that items on security and support loaded onto the same factor it would seem that perceptions that the level of technical support available is low, and specifically that it is lower than for other e-government websites that the respondents have used, fuels concerns about the 'safeness' of the website. $87.2 \%$ either strongly disagreed or disagreed with the statement that 'Technical support available at the NIS website is as good as other e-government websites used'. Most users either agreed or strongly agreed that 'There is a lack of technical support while using the NIS website' (87.2\%) or 'It is difficult to seek technical support from the NIS website team' (87.4\%). This analysis is consistent with data from the open question:

struggle sometimes to get things done and there is nobody around to guide me on what to do'

'the technical support to the website needs to be improved to give users more support in difficult situations most especially during financial transactions'

Concern with security of e-government services, particularly in the arenas of privacy and the use of personal data and financial transactions, has been mentioned by various authors (Dibbell, 2012; Parker, 2011; Gilbert et al., 2004;). This study provides further evidence for Colesca (2009)'s suggestion that security and privacy issues hinder the user experience concerning e-government websites. In addition, security and privacy would appear to be of particular concern in the context of Nigerian e-government services (Kazeem, 2011; Mundy and Musa, 2010); this is quite possibly associated with concerns about the trustworthiness of government (Mutimukwe et al., 2017; Ciborra, 2005;).

In respect of security and support, previous studies have also that indicated that technical support provided by e-government websites can have a significant effect on the user experience of e-government e-services (Kotamraju and Van der Geest, 2011). More 
specifically, the provision of technical support may affect the perception of service credibility (Bertot et al., 2008) and may therefore have links to trust and perceptions of security.

\section{Trust}

Findings on trust serve to further emphasise issues raised in response to questions on security and support, suggesting that whilst trust is a separate factor it is tightly coupled with notions of security. For example, in response to the question: 'The NIS website is safe to conduct financial transactions' $75.4 \%$ either strongly disagreed or disagreed, and in response to the question 'The NIS website provides adequate measure to protect my financial details (credit or debit card)', $80.6 \%$ either strongly disagreed or disagreed. On the other hand, whilst responses to questions on the protection and disclosure of personal information were also, generally negative, they were less so, perhaps suggesting a lower level of concern regarding the risk associated with their personal data than the risk associated with financial data.

Responses to other questions were ambivalent, with overall means around 3 and significant percentages of the responses in the neither agree nor disagree category. For example, the question 'The information that I give on the NIS website is only used for the reason for which it is submitted' had 50.8\% responses as neither agree nor disagree, and 'My information is only accessed by the authorised person' had $48.6 \%$ neither agree nor disagree. The question with the highest level of non-commitment was 'The NIS website has a good reputation' with $73.7 \%$ neither agree nor disagree. Whilst such ambivalence may be better than negativity, it does not suggest any positive trust or confidence in the service. Examples of comments include:

'assurance needs to be given to the user that their data will not be used for any other thing than what they have submitted it for at the government website'

'the user needs to be happy that their information will be protected'

\section{Ease of Use}

Responses to the statements on ease of use, with one exception, are much less polarised than responses on security and support, and trust, indicating generally weaker feelings. The exception is the response to the question: 'I find that completing transactions on the NIS website is easy for me', where $75.7 \%$ either strongly disagreed or disagreed. This contrasts with the responses to 'I find that obtaining information from the NIS website for my needs is easy', where there was a little less negativity with only $2.8 \%$ strongly disagreeing and $55.3 \%$ 
disagreeing. It appears, then that conducting transactions is regarded as more problematic than finding information. This concern is supported by the following comment: 'the NIS needs to simplify their payment process while strengthening their website security policy. However, a minority of the respondents commented that they 'found the entire process easy and uncomplicated'.

The two statements regarding whether using the e-service is easy, and whether the website is user friendly, surprisingly, attracted rather different patterns of responses. The responses to the statement 'I find that using e-services at the website of the NIS is easy' were split with the largest groups of respondents either agreeing (40.7\%) or disagreeing (40.5\%), whereas, for the question 'I find that the NIS website is user friendly, 15.7\% agreed, and 59.8\% disagreed. These suggest that there is some satisfaction with the functionality or utility of the website, but a relatively high level of negativity when invited to think of it as 'friendly'. The pattern clustering across the three middle categories also characterises the responses to most of the other questions in this section, In all instances, other than those already discussed, the disagree group is larger than the agree group, leading to a group of statements with means below 3, suggesting a pervading dissatisfaction with aspects of the website, such as navigation, layout, and easy of finding things quickly. However, it is important to observe that for several of these questions, and most notably the one on navigation, there are sizeable numbers of respondents who are positive about aspects of the website.

Furthermore, some respondents commented that 'they struggle sometimes to get things done...' and mentioned the group of people who are particularly exposed: '...it is difficult for non-frequent users of the Internet...' as they have to find way to do it on their own when: '...there is nobody around to guide me on what to do.'

\section{Website quality}

Responses on website quality were also negative. All statements apart from the negative one 'I always have problems using the NIS website' have means below 3. For this statement $48.7 \%$ agree and $27.9 \%$ are neutral. For the other statements, the pattern is similar to that for ease of use, with most responses lying in the middle three categories, and the largest group being in the disagree category, but with sizeable groups also in the neutral, and agree categories. This means that respondents generally do not agree that using the website is a 
pleasant experience, the website adequately needs their needs, or that they feel adequately informed, or empowered. It was suggested that 'the design is poor', 'the website needs to be more user friendly' and it 'looked unprofessional'. There were several negative comments regarding navigation:

'difficult to navigate and conduct a transaction'

'hard to follow and you will have to juggle around until you find what you are looking for which is waste of time and money especially when using a cybercafé to browse the internet.'

Nevertheless, there was an acknowledgment that this was 'one of the best websites amongst Nigerian websites' and that it 'speeded up both application and visa processes'

Given the limited prior studies on the user experience of Nigerian websites, it is difficult to know whether the generally ambivalent comments about ease of use and website quality in this study are unique. However, Yusuf (2006) suggests that the implementation of egovernment in Nigeria could be more user-centric, and, in their limited study based on the content analysis of some Nigerian websites, Mundy and Musa (2010) concluded that these sites had low usability. Overall, however, this study provides evidence that the design of the NIS website could be improved, although it has to be acknowledged that the relative complexity of e-government websites and the relative inexperience of some users might make this more challenging.

\section{Content and Information}

In contrast to the negative or ambivalent responses above, the majority of the respondents were positive when asked about the issues of content and information provided by the NIS on their website. The responses revealed that $61.9 \%$ of the respondents agreed or strongly agreed that 'There is adequate information on the NIS website for me to process any transaction' and $68.9 \%$ agreed or strongly agreed that 'The content of the website is useful for my purpose'. Only $45 \%$ either agreed or strongly agreed that the content was reliable, although there was also a large neutral group (41\%). Means for accuracy and format were low at 2.8 and 2.69, respectively. Some responses to the open question cited limitations:

'inadequate information to complete passport application successfully'

'government should provide accurate information.'

But others were more positive:

'the information provided was adequate for what I needed' 
'it provided the process of e-passport application and the addresses of consulates'

Delone and McLean (1992) highlighted the importance of content and information to the user of e-government services and this has been re-iterated by others who comment on the desirable features of web site content (e.g. Bertot et al., 2008; Yoon et al., 2008).

\section{Perceived Benefits}

The responses on the perceived benefits of using the NIS e-services were mixed. For example, for 'I do not consider the NIS website of any benefit to me' over 80\% strongly disagree or disagree, which implies that the majority considered NIS e-services to be beneficial to them, and $60.9 \%$ either agreed or strongly agreed that using the NIS website improved the effectiveness of their visa/passport application. However, the responses to some of the other questions were split, with, for instance 37.5\% disagreeing and 31.1\% agreeing that 'Making use of the NIS website reduces my travelling expenses', and 29.6\% disagreeing and 39.6\% agreeing that 'Making use of the NIS website reduces my queuing time'. Respondents commented that it was 'better than the face to face procedure used in the past'. Others suggested mobile channels would be even more beneficial: '...internet on the mobile is cheaper...' and provides greater '...convenience of access...' .

\section{Convenience}

Responses on convenience were the most positive. Respondents commented positively on the ability to be able to use the NIS website how, where and when they want, with $90 \%$ of the respondents agreeing or strongly agreeing to 'I am able to use NIS e-services at a time that suits me' and 'I am able to use NIS e-services from anywhere in the world' and with over $80 \%$ agreeing or strongly agreeing to the question I I am able to accomplish tasks more quickly using the NIS website compare to face-to-face service'. Respondents commented:

'gives you some opportunity to do things at your own time'

However, some respondents had some negative comments to make about convenience, especially if they did not have easy access to the Internet:

'have to travel to another city in order to use the cybercafé at a time and place that is not convenient for me'

'have to wait for the opening of the cybercafé at a time that is not suitable for me'

'the government needs to provide facilities to make it possible to access e-services in libraries or special centres' 
Overall, users of the NIS do perceive the availability of the service to offer convenience, particularly in the light of the anytime, anywhere nature of the service. Others have commented on the importance of convenience and the ability to use the e-government services how, when and where they want it (Meuter et al., 2000; Zhu et al., 2002). According to Kim et al., (2006), convenience has a significant effect on customer satisfaction with the egovernment experience and should not be ignored.

\section{Perceived Barriers}

The means for most of the questions relating to barriers are between 3 and 4 (between agree and disagree), however, opinions on most questions are also divided. For instance, 31.6\% disagree, and $32.8 \%$ agree that 'It is costly to have Internet access in order to use government services'. For other questions the divide is even more evident, with $32.8 \%$ disagreeing and $42.5 \%$ strongly agreeing that 'An intermittent electricity supply makes it difficult for me to use NIS e-services'. In addition, $60.7 \%$ either agree or strongly agree that 'Lack of access to a computer results in extra cost in using NIS e-services. Comments in response to the open question focussed on the common impediments to the effective use of the NIS e-services. Some mentioned the intermittent '...electricity supply...' while some commented on the spiralling increase in the cost of '...access to the internet...' and others suggested that with the high rate of unemployment that '... when you have no job or on a low wage...' it is difficult to make use of the NIS e-service. Some respondents commented further on electricity supplies:

'electricity needs to be improved, because even if you have the computer and access to the internet, if there is no electricity supply, it is useless'

'the cost of powering / fuelling a generator for electricity is too much for low income people and students,

Other respondents commented on the cost of travelling from one location to another to use the NIS e-service:

'there is a need to help people living in rural areas by establishing an Internet centre rather than expecting them to travel a very long distance to a city where they can find the Internet'

'It's costing more to travel, wasting precious time and there may be no electricity even when you reach the city where you want to use the Internet at a cybercafé'

Finally, some respondents proposed that: 
'the government needs to upgrade the infrastructure for both electricity and telephone to pave the way for cheap affordable internet access.'

Taking the data on barriers and benefits together, it is evident that NIS e-services work better for some users than others, depending on Internet access and the reliability of electricity supplies. This is not surprising, since many authors have suggested that these are major issues for e-government in developing countries (Dimitrova and Chen, 2006; Schaupp and Carter, 2005; Asogwa, 2013). Amagoh (2016) found that obsolete ICT infrastructure, intermittent electricity supply, lack of privacy and protection of users data, and poor internet access were hindering the adoption and use of e-government services in Nigeria. Of particular interest is that the sample in this study is relatively well educated and prosperous, and yet many of them still face such difficulties.

\section{Reflections on Findings}

Content and information, convenience, and benefits: According to Hazlett and Hill (2003), the government's success when using the internet to deliver its messages strongly depends on the content displayed on its website and such information being made available for users' convenience, anytime and anywhere. Furthermore, Carter and Bélanger (2005), suggest that the benefits received from the use of an e-government portal can result in the user loyalty and satisfaction. Ramon et al. (2007) note that the content available on such websites saves users' time and allows them to navigate and extract relevant information easily. Halaris et. al. (2007) points to the convenience of having access to good and accurate information on government websites as it enables users to make accurate decisions and reap the benefits of using such websites.

Website quality, security and support, and trust: The quality of a website increases users' trust and engenders positive views of its security and, also reduces their reliance on technical support (Aladwani and Palvia, 2002; Hariguna et al., 2017) and well as promoting userfriendliness and the protection of personal information (Aladwani, 2013). Website quality contributes strongly to formulating individual perceptions and hence leads to a decreased reliance on support when using the site (Elling et al., 2012). Inadequate security and support may affect users' willingness to make frequent visits to a government's website (Al-rawahna, et al., 2018) as citizens' perceptions of website quality may affect their trust in an egovernment service (Alenezi et al., 2017). 
Barriers, and ease of use: Gilbert et al. (2004) state that a barrier in technological terms is a risk that makes users wary of becoming engaged with an activity. Barriers restrict citizens' feelings of control when using a website and affect their satisfaction with the use of egovernment websites (Alenezi et al., 2017). In other words, ease of use is a vital factor affecting the adoption and satisfaction of e-government services (Wangpipatwong, et al., 2008). When using government services on electronic platforms is free of effort or difficulty, the barriers to using such services are reduced (Beldad et al., 2012). If users can complete and perform a transaction effectively on the NIS portal with relative ease, they will be more willing to use the online service.

\section{Conclusion and recommendations}

\section{Conclusion}

Some of the findings from this study, especially those relating to security and support and trust may appear to be very negative. Indeed, there is wider evidence that hints that the citizens of some developing countries have every reason to be skeptical about the actions of their governments. Add to this the challenges associated with achieving reliable information systems implementations in some developing countries, and the relative novelty of information technology for some citizens, it is not surprising that citizens might have concerns about the security of the personal and financial data that they are required to load into such systems. Accordingly, progressing effective e-government is likely to require a three-pronged approach, including systems and technology development, strengthening of governance, equity and transparency of political, economic and social aspects of government, and developing citizen information technology literacies and competencies. In other words, the solution does not lie with systems alone. Further, this study confirms that Nigeria is one of those developing countries in which the potential benefits of e-government services are not always realized in practice, because citizens do not have access to reliable electricity supplies and internet connectivity. In particular, mobile technologies, which involve the development of mobile-enabled e-government services, may contribute to navigating some of the more intractable infrastructure problems.

However, some of the challenges facing the NIS e-services, and possibly other e-government services in Nigeria derive from the design of the websites and their associated systems. Whilst the users in this study reported most negatively on security and privacy, and on barriers such 
as intermittent electricity supplies and internet access, they were also relatively negative regarding ease-of-use, web site quality, and content and information on the website. Maybe this is partly because the users in this study are not willing adopters of the NIS e-services; they are conscripts. In addition, they are relatively well educated, and by virtue of their use of the NIS service are likely to be relatively well travelled, and many will have experience of commercial websites and e-government websites in other countries. Accordingly, they may have high expectations of websites and e-services. Nevertheless, there is a sense that there is scope for improvement in the website design.

The most positive message from this study is that users perceive that e-government services can be convenient and effective - the challenge is for governments to deliver on these potential benefits.

\section{Recommendations for practice}

First, we offer a range of recommendations for practitioners, and especially those responsible for designing and delivering the NIS e-services:

1. Develop perceptions of security through appropriate security and privacy policy statements, and through offering adequate and easily accessible online or telephonebased support.

2. Conduct further development of the user interface for the website, based on further consultation with users as to the way in which they use the website. This consultation should include both expert and novice computer users.

3. In future redesigns of the website, pay particular attention to navigation, and to the inclusion of useful and targeted content and information.

4. Explore the options for and benefits of mobile technologies for e-government delivery.

5. Explore the potential role of social media in e-government, as this could be a new means of engaging users with e-government services.

6. Seek ways to improve on citizen perception of the trustworthiness of the service, as this is likely to improve more adoption of e-government services and citizen confidence.

7. Invest in basic infrastructures such as electricity and internet access; these are essential to successful implementation of e-government and other digital services. 


\section{Recommendations for research}

Further research into the user experience of e-government services in developing countries should be conducted to generate more detailed insights into the problem and challenges associated with the delivery of specific types of e-government services in different countries. It would be particularly worthwhile to further explore the potential of mobile technologies. There is also scope for studies into other e-government services in Nigeria, and for comparative studies between Nigeria and other developed and developing countries. In addition, qualitative studies would generate greater insights into the way in which egovernment services can support citizen's interactions with, and confidence in their governments.

\section{References}

Abdulkareem, A.K. (2015), "Challenges of e-government implementation in the Nigerian public service", Journal of Creative Writing, Vol.1 No.4, pp.45-56.

Abu-Shanab, E.A. (2017), "E-government familiarity influence on Jordanians' perceptions", Telematics and Informatics, Vol.34 No.1, pp.103-113.

Adeniran, A. (2008), "The internet and emergence of Yahooboys sub-culture in Nigeria", International Journal of Cyber Criminology, Vol.2 No.2, pp.368 - 381.

Adeyemo, A. (2011), "E-government implementation in Nigeria: An assessment of Nigeria's global e-gov ranking”. Journal of Internet and Information Systems, Vol.2 No.1, pp.11-19.

Akunyili, D. (2010), "ICT and e-government in Nigeria: opportunities and challenges", An address delivered at the World Congress on Information Technology, Amsterdam, Netherlands, 25-27 May, 2010.

Al Ajeeli, A. and Al-Bastaki, Y. (2011). Handbook of Research on E-services in the Public Sector. Hershey PA: Information Science Reference.

AL Athmay, A.A.A., Fantazy, K. and Kumar, V. (2016), "E-government adoption and user's satisfaction: an empirical investigation", EuroMed Journal of Business, Vol.11 No.1, pp.5783.

Aladwani, A. (2013), "A cross-cultural comparison of Kuwaiti and British citizens' views of e-government interface quality", Government Information Quarterly, Vol. 30 No 1, pp.74-86. Aladwani, A. and Palvia, P. (2002), "Developing and validating an instrument for measuring user-perceived web quality", Information \& Management, Vol.39 No.6, pp.467-476.

Alenezi, H., Tarhini, A., Masa'deh, R.E., Alalwan, A. and Al-Qirim, N. (2017), "Factors affecting the adoption of e-government in Kuwait: A qualitative study", Electronic Journal of e-Government, Vol. 15 No 2.

Al-Hakim, L. (2007), “The role of government in e-business adoption”, In: L. Al-Hakim, ed., Global E-government: Theory, Applications and Benchmarking, IGI, Hershey, PA; pp. 65-84. Al-rawahna, A.S.M., Chen, S.C. and Hung, C.W. (2018), "The barriers of e-government success: an empirical study from Jordan", International Journal of Managing Public Sector Information and Communication Technologies, Vol. 9 No. 2, pp.1-18.

Al-Refaie, A. and Ramadna, A.M. (2017), "Barriers to e-government adoption in Jordanian organizations from users' and employees' perspectives", International Journal of Electronic Government Research, Vol.13 No.1, pp.33-51. 
Amagoh, F. (2015), "An assessment of e-government in a West African country: the case of Nigeria”, International Journal of Public Administration in the Digital Age, Vol.2 No.3, pp.80-99.

Amagoh, F. (2016), "Determinants of e-government diffusion in Nigeria: an examination of theoretical models", Information Development, Vol.32 No.4, pp.1137-1154.

Aneke, F. (2009). Talking telecommunications in Nigeria. [online] Dynamicexport. Available at: $\quad$ http://www.dynamicexport.com.au/articles/industries/talking-telecommunications-innigeria/ [Accessed 19 Jan 2018].

Ashaye, O.R. and Irani, Z., (2014), "E-government implementation benefits, risks, and barriers in developing countries: evidence from Nigeria", US-China Education Review, Vol.4 No.1, pp.13-25.

Asogwa, B. E. (2013), "Electronic government as a paradigm shift for efficient public services: Opportunities and challenges for Nigerian government", Library Hi Tech, Vol. 31 No. 1, pp.141 - 159

Beldad, A., van der Geest, T., de Jong, M. and Steehouder, M. (2012), “A cue or two and I'll trust you: determinants of trust in government organizations in terms of their processing and usage of citizens' personal information disclosed online", Government Information Quarterly, Vol. 29 No. 1, pp.41-49.

Bertot, J.C., Jaeger, P.T. and McClure, C.R. (2008), "Citizen-centered e-government services: benefits, costs, and research needs", In: Proceedings of the 9th Annual International Digital Government Research Conference. Montreal, Canada, 2008.

Carter, L. and Belanger, F. (2005), "The utilization of e-government services: citizen trust, innovation and acceptance factors", Information Systems Journal, Vol.15 No.1, pp. 5-25.

Carter, L., Weerakkody, V., Phillips, B. and Dwivedi, Y.K. (2016), "Citizen adoption of egovernment services: exploring citizen perceptions of online services in the United States and United Kingdom", Information Systems Management, Vol.33 No.2, pp.124-140.

Ciborra, C. (2005), "Interpreting e-government and development efficiency, transparency or governance at a distance," Information Technology and People, Vol.18 No.3, pp. 260-79.

Colesca, S.E. (2009), "Increasing e-trust: a solution to minimize risk in e-government adoption", Journal of Applied Quantitative Methods, Vol.4 No.1, pp 31-44.

Creswell, J.W. and Creswell, J.D., (2017), Research Design: Qualitative, Quantitative, and Mixed Methods Approaches. Thousand Oaks: Sage Publications.

Davis, F. D., Bagozzi, R. P. and Warshaw, P. R. (1989), "User acceptance of computer technology: a comparison of two theoretical models", Management Science, Vol. 35 No.8, pp. 982-1003.

DeLone, W. H. and McLean, E. R. (1992). "Information system success: the quest for dependent variable", Information System Research, Vol. 3 No.1, pp. 60-95.

Dibbell, J. (2012), "The Shadow Web”, Scientific American, Vol.306 No.3, pp. 60-65.

Dimitrova, D.V. and Chen, Y. (2006), "Profiling the adopters of egovernment information services: the influence of psychological characteristics, civic mindedness, and information channels", Social Science Computer Review, Vol.24 No. 2, pp.172-88.

Dwivedi, Y.K. (2009), E-Government Development and Diffusion: Inhibitors and Facilitators of Digital Democracy. IGI, Hersey, PA.

Elling, S., Lentz, L., de Jong, M. and van den Bergh, H. (2012), "Measuring the quality of governmental websites in a controlled versus an online setting with the 'website evaluation questionnaire"”, Government Information Quarterly, Vol. 29 No. 3, pp.383-393.

Gilbert, D., Balestrini, P. and Littleboy, D. (2004), "Barriers and benefits in the adoption of egovernment”, International Journal of Public Scetor Management, Vol.17 No.4, pp. 286-301. 
Gunawong, P. and Gao, P., (2017), "Understanding e-government failure in the developing country context: a process-oriented study", Information Technology for Development, Vol.23 No.1, pp.153-178.

Halaris, C, Magoutas, B, Papadomichelaki, X. and Mentzas, G. (2007), "Classification and synthesis of quality approaches in e-government services", Internet Research, Vol.17 No.4, pp 378-401.

Hariguna, T., Lai, M.T., Hung, C.W. and Chen, S.C. (2017), "Understanding information system quality on public e-government service intention: an empirical study", International Journal of Innovation and Sustainable Development, Vol. 11 No. 2, pp.271-290.

Hassan, H.S., Shehab, E. and Peppard, J. (2011), "Recent advances in e-service in the public sector: state-of-the-art and future trends", Business Process Management Journal, Vol.17 No.3, pp 526-545

Hazlett, S. and Hill, F. (2003), "E-government: the realities of using IT to transform the public sector", Managing Service Quality: An International Journal, Vol. 13 No. 6, pp.445452.

Heeks, R. (2006). Implementing and managing eGovernment: An international Text. Sage Publications, London.

Idowu, A.O., Idowu, P.A. and Adagunodo, E.R. (2009), "Empirical study on information and communication technology and youth in a developing country: Nigeria as a case", International Journal of Information Technology \& Decision Making, Vol.4 No.2, pp.297309.

Kanat, İ.E and Ozkan, S. (2009), "Explaining citizen adoption of government to citizen services: a model based on theory of planned behaviour", European and Mediterranean Conference on Information Systems, Vol.14 No.3, pp.1-12.

Kazeem, A. (2011), "Legal aspects of e-payment in government", [online], The Nigerian Law Guru.

http://www.nigerianlawguru.com/articles/general/LEGAL\%20ASPECTS\%20OF\%20EPAYMENT\%20IN\%20GOVERNMENT.pdf

Kim, M., Kim, J. and Lennon, S.J. (2006), "Online service attributes available on apparel retail websites: An E-S-QUAL Approach”, Managing Service Quality, Vol. 16 No.1, pp.51 77.

Kotamraju, N.P. and Van der Geest, T.M. (2011), "The tension between user-centred design and e-government services", Behaviour \& Information Technology, Vol. 31 No.3, pp. 261-73. Lee, C.B. and Lei, U.L. (2007), "Adoption of egovernment services in Macao", In: Proceedings of the 1st International Conference on Theory and Practice of Electronic Governance., 2007. ACM Conference Proceeding Series.

Liao, Z. and Cheung, M.T. (2001), "Internet-based e-shopping and consumer attitudes: an empirical study”, Information \& Management, Vol.38 No.5, pp.299-306.

Liao, Z. and Cheung, M.T. (2002), "Internet-based e-banking and consumer attitudes: an empirical study", Information \& Management, Vol. 39, No.4, pp. 283-95.

Meuter, M.L., Ostrom, A.L., Roundtree, R.I. and Bitner, M. J. (2000), "Self-service technologies: understanding customer satisfaction with technology-based service encounters", Journal of Marketing, Vol. 64 No. 3, pp 50-64.

Mundy, D. and Musa, B. (2010), "Towards a framework for eGovernment development in Nigeria", Electronic Journal of E-Government, Vol.8 No.2, pp.148-161.

Mutimukwe, C., Kolkowska, E. and Grönlund, Å. (2017), "Trusting and adopting egovernment services in developing countries? Privacy concerns and practices in Rwanda". In: International Conference on Electronic Government (pp. 324-335). Cham:Springer 
Okwuke, E. (2013). New ICT policy as catalyst for national development. [online] Daily Independent, Available at: http://dailyindependentnig.com/2013/04/new-ict-policy-ascatalyst-for-national-development/ [Accessed 19 Jan. 2018].

Olasina, G. (2012), "A review of e-government services in Nigeria", Indian Journal of Library and Information Science, Vol. 6, No.3, pp.301-305.

Omeire, E., and Omeire, C. (2014), "New wine in old wine skin: an exploration of major constraints to e-government implementation in Nigeria", European Scientific Journal, Vol.10, pp.481-487.

Oni, A.A., Ayo, C.K., Oni, S. and Mbarika, V.W. (2016), "Strategic framework for edemocracy development and sustainability", Transforming Government: People, Process and Policy, Vol.10 No.3, pp.457-477.

Oppenheim, A.N., (2000), "Questionnaire Design, Interviewing and Attitude Measurement", London: Bloomsbury Publishing.

Parasuraman, A., Zeithaml, V.A. and Malhotra, A. (2005), "E-S-QUAL: a multiple-item scale for assessing electronic service quality", Journal of Service Research, Vol.7 No.3, pp. 213-33. Parent, M., Vandebeek, C., and Gemino, A. (2005), "Building citizen trust through egovernment", Government Information Quarterly, Vol.22 No.4, pp.720-736.

Parker, J.S. (2011), "Lost in the cloud: protecting end-user privacy in federal cloud computing contracts", Public Contract Law Journal, Vol.41 No.2, pp.385-409.

Praeg, C. P. and Spath, D. (2010), Quality Management for IT Services: Perspectives on Business and Process Performance. IGI, Hersey, PA.

Ramon Gil-Garcia, J., Chengalur-Smith, I. and Duchessi, P. (2007), "Collaborative egovernment: impediments and benefits of information-sharing projects in the public sector", European Journal of Information Systems, Vol. 16 No. 2, pp.121-133.

Rana, N.P. and Dwivedi, Y.K., (2015), "Citizen's adoption of an e-government system: Validating extended social cognitive theory (SCT)", Government Information Quarterly, Vol.32 No.2, pp.172-181.

Reddick, C.G. (2010). Comparative E-Government. Springer.

Rokhman, A. (2011), "E-Government adoption in developing countries; the case of Indonesia", Journal of Emerging Trends in Computing and Information Sciences, Vol.2 No.5, pp.228-36.

Rowley, J. (2006), "An analysis of the e-service literature: towards a research agenda", Internet Research, Vol. 16 No. 3, pp. 339-59.

Sampson, A., Bakht, H. and Desta, A. (2018), "The factors affecting citizens' adoption of egovernment systems in developing countries: Nigeria case study", Journal of Computing and Management Studies, Vol.2 No.1

Schaupp, L.C. and Carter, L. (2005), "E-voting: from apathy to adoption", Journal of Enterprise Information Management, Vol.18 No.5, pp.586-601.

Scott, M., DeLone, W. and Golden, W. (2016). Measuring eGovernment success: a public value approach", European Journal of Information Systems, Vol. 25 No.3, pp.187-208.

Siddiquee, N.A. (2016), "E-government and transformation of service delivery in developing countries: the Bangladesh experience and lessons", Transforming Government: People, Process and Policy, Vol.10 No.3, pp.368-390.

Waller, L. and Genius, A. (2015), "Barriers to transforming government in Jamaica: challenges to implementing initiatives to enhance the efficiency, effectiveness and service delivery of government through ICTs (e-Government)", Transforming Government: People, Process and Policy, Vol.9 No.4, pp.480-497.

Wangpipatwong, S., Chutimaskul, W. and Papasratorn, B. (2008), "Understanding citizen's continuance intention to use e-government website: a composite view of technology 
acceptance model and computer self-efficacy", The Electronic Journal of e-Government, Vol. 6 No. 1, pp.55-64.

Yonazi, J., Sol, H. and Albert Boonstra, A. (2010), "Exploring issues underlying citizen adoption of egovernment Initiatives in developing countries: the case of Tanzania", Electronic Journal of e-Government, Vol.8 No.2, pp.176-88.

Yoo, B. and Donthu, N. (2001), "Developing a scale to measure the perceived quality of an internet shopping site (Sitequal)", Quarterly Journal of Electronic Commerce, Vol.2 No.1, pp.31-46.

Yoon, S.-Y., Laffey, J. and Oh, H. (2008), "Understanding usability and user experience of web-based 3D graphics technology", International Journal of Human-Computer Interaction, Vol,24 No.3, pp. 288-306.

Yusuf, O. (2006), Solutions for Egovernment Development in Nigeria, Accenture EIU Government Research.

Zhang, X. and Prybutok, V.R. (2005), "A consumer perspective of e-service quality", IEEE Transactions on Engineering Management, Vol. 52 No.4, pp 461-477.

Zhu, F.X., Wymer, W. and Chen, I. (2002), "IT-based services and service quality in consumer banking", International Journal of Service Industry Management, Vol. 13 No. 1, pp. 69-90. 
Appendix 1 - Findings

\begin{tabular}{|c|c|c|c|c|c|c|c|c|}
\hline Variables & Items & Mean & SD & 1 & 2 & 3 & 4 & 5 \\
\hline \multirow{9}{*}{$\begin{array}{l}\text { Security and } \\
\text { Support } \\
\text { (CA: 0.91) }\end{array}$} & I worry about my financial details being stolen & 4.29 & 0.760 & 0.90 & 2.50 & 5.70 & 48.70 & 42.20 \\
\hline & I have no negative reason not to use NIS website & 1.88 & 0.907 & 35.90 & 50.70 & 4.80 & 6.80 & 1.80 \\
\hline & I worry about safe transactions online & 4.32 & 0.740 & 0.90 & 2.60 & 3.70 & 49.80 & 43.00 \\
\hline & I worry about my personal information being used by others & 4.31 & 0.751 & 0.90 & 3.10 & 2.80 & 50.40 & 42.80 \\
\hline & $\begin{array}{l}\text { The NIS website well designed compared to other e-government websites } \\
\text { that I have used }\end{array}$ & 1.70 & 0.892 & 51.30 & 35.30 & 6.80 & 5.70 & 0.90 \\
\hline & There is lack of technical support while using NIS website & 4.30 & 0.920 & 1.70 & 5.10 & 6.00 & 35.30 & 51.90 \\
\hline & $\begin{array}{l}\text { Technical support available at the NIS website is as good as other e- } \\
\text { government websites used }\end{array}$ & 1.68 & 0.867 & 51.90 & 35.30 & 6.80 & 5.40 & 0.60 \\
\hline & $\begin{array}{l}\text { The NIS website security policy is clearly stated and accessible to the } \\
\text { users of the website to read }\end{array}$ & 1.70 & 0.922 & 53.00 & 31.80 & 8.00 & 6.30 & 0.90 \\
\hline & It is difficult to seek technical support from NIS website team & 4.34 & 0.869 & 1.40 & 3.40 & 7.80 & 35.00 & 52.40 \\
\hline \multirow{9}{*}{$\begin{array}{l}\text { Trust } \\
(\mathrm{CA}: 0.90)\end{array}$} & The NIS website is safe to conduct financial transactions & 2.08 & 0.975 & 29.80 & 45.60 & 12.30 & 11.40 & 0.90 \\
\hline & $\begin{array}{l}\text { The NIS website provides adequate measures to protects my financial } \\
\text { details (credit or debit card) }\end{array}$ & 1.88 & 0.896 & 38.70 & 41.90 & 12.50 & 6.30 & 0.60 \\
\hline & I am happy to provide my personal information at the NIS website & 2.41 & 1.054 & 17.90 & 46.70 & 13.40 & 20.20 & 1.80 \\
\hline & The NIS website protect my disclosed personal information & 2.38 & 0.909 & 16.50 & 40.50 & 31.80 & 10.30 & 0.90 \\
\hline & $\begin{array}{l}\text { The information that I give on the NIS website is only used for the reason } \\
\text { for which it is submitted }\end{array}$ & 2.72 & 0.781 & 5.40 & 31.30 & 50.80 & 11.40 & 1.10 \\
\hline & My information is only accessed by the authorised person & 2.68 & 0.790 & 6.30 & 32.80 & 48.60 & 11.40 & 0.90 \\
\hline & The NIS website has a good reputation & 3.04 & 0.544 & 0.30 & 11.10 & 73.70 & 14.00 & 0.90 \\
\hline & $\begin{array}{l}\text { I feel confident that I can rely on transactions conducted through the NIS } \\
\text { website }\end{array}$ & 3.05 & 0.896 & 2.60 & 27.90 & 34.20 & 33.00 & 2.30 \\
\hline & $\begin{array}{l}\text { I feel confident that the NIS will meet their obligations for transactions } \\
\text { conducted through their website }\end{array}$ & 3.12 & 0.880 & 2.00 & 23.90 & 37.70 & 33.00 & 3.40 \\
\hline \multirow{5}{*}{$\begin{array}{l}\text { Ease of Use } \\
(\mathrm{CA}: 0.91)\end{array}$} & I find that using e-services at the website of the NIS is easy & 3.01 & 0.952 & 0.90 & 40.50 & 16.50 & 40.70 & 1.40 \\
\hline & I find that navigating around the NIS website is easy & 2.71 & 0.953 & 2.30 & 56.10 & 10.50 & 30.20 & 0.90 \\
\hline & I find that the NIS website is user friendly & 2.50 & 0.835 & 3.90 & 59.80 & 19.70 & 15.70 & 0.90 \\
\hline & The NIS website layout makes it easy for me to find things at first sight & 2.33 & 0.767 & 3.40 & 73.80 & 10.30 & 11.40 & 1.10 \\
\hline & I feel comfortable using the NIS website & 2.98 & 0.944 & 1.40 & 39.60 & 20.50 & 36.80 & 1.70 \\
\hline
\end{tabular}




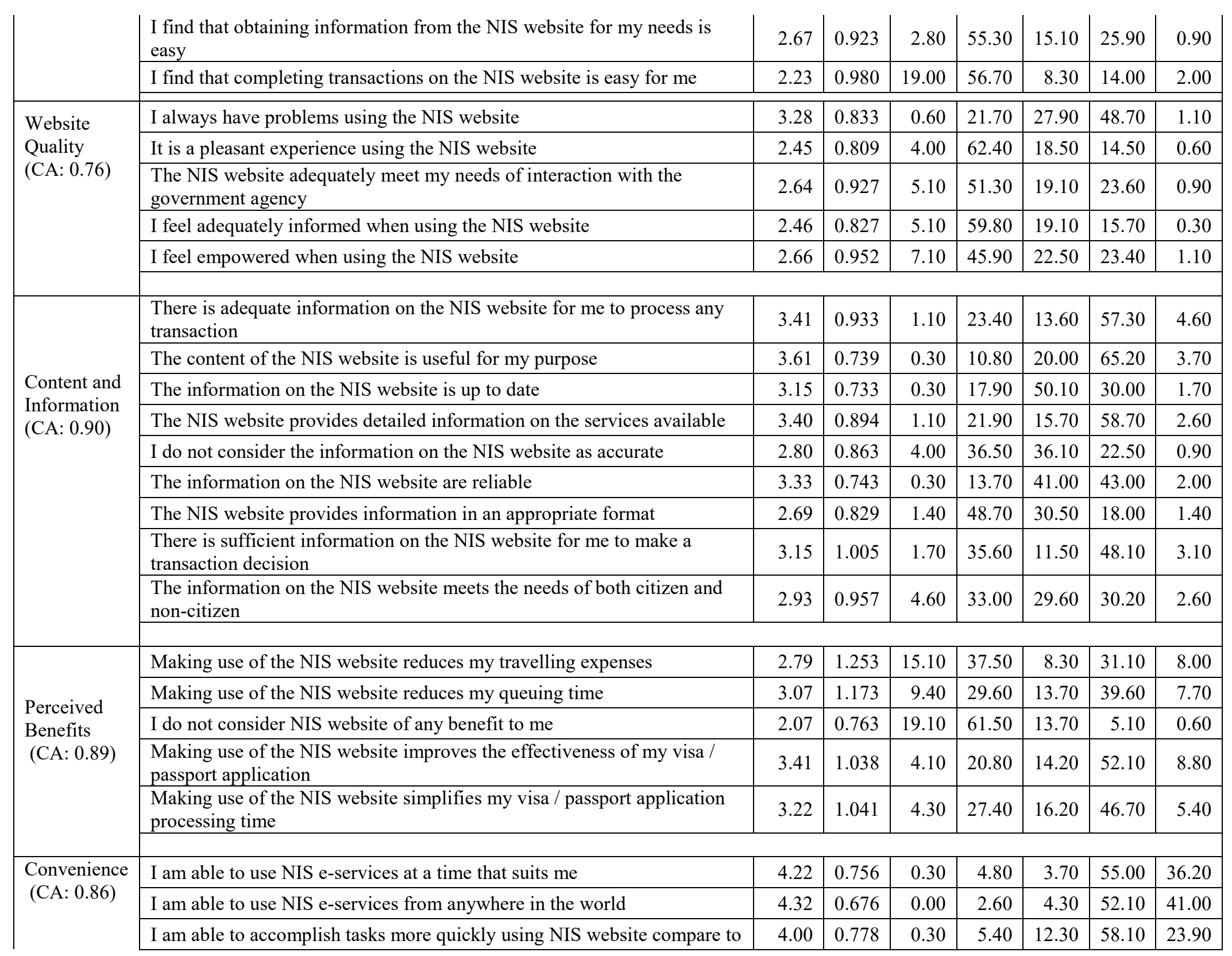




\begin{tabular}{|c|c|c|c|c|c|c|c|c|}
\hline & \multicolumn{8}{|l|}{ face-to-face service } \\
\hline & $\begin{array}{l}\text { Making use of the NIS website reduces the time associated with my } \\
\text { initial enquiry }\end{array}$ & 2.15 & 1.062 & 29.60 & 43.30 & 12.00 & 12.50 & 2.60 \\
\hline \multirow{4}{*}{$\begin{array}{l}\text { Perceived } \\
\text { Barriers } \\
\text { (CA:0.93) }\end{array}$} & It is costly to have internet access in order to use government e-services & 3.21 & 1.316 & 9.10 & 31.60 & 7.40 & 32.80 & 19.10 \\
\hline & $\begin{array}{l}\text { An intermittent electricity supply makes it difficult for me to use NIS e- } \\
\text { services }\end{array}$ & 3.38 & 1.548 & 10.70 & 32.80 & 6.30 & 7.70 & 42.50 \\
\hline & Lack of access to a computer results in extra cost in using NIS e-services & 3.55 & 1.357 & 6.80 & 25.70 & 6.80 & 27.40 & 33.30 \\
\hline & Using NIS website to apply for passport or visa may cost me more & 2.96 & 1.172 & 9.10 & 36.80 & 9.10 & 38.70 & 6.30 \\
\hline
\end{tabular}

